\title{
The Actual Use of Green Spaces by Children and Parents in Malang, Indonesia
}

\author{
Sri Een Hartatik, Akemi Itaya* \\ Graduate School of Bioresources, Mie University, Mie, Japan 514-8507
}

Received October 24, 2018/Accepted December 21, 2018

\begin{abstract}
Green spaces in developing countries are often destroyed and degraded for other land uses. As increases in urbanization and population continue in Indonesia, it will be increasingly important to discuss green spaces around children. In this study, the actual use of urban green spaces by children was investigated through questionnaires for children and their parents, and the strategy for increasing opportunity to use urban green spaces was discussed in Malang, a region of progressing urbanization in Indonesia. A total of 147 questionnaires were received from the children and 145 from their parents. While there were few green spaces around schools in Malang, especially in the center of the city, fortunately, children liked to play in the outside more than other studies. However, children preferred to spend their time in well-maintained or level areas, such as parks and open fields. It might be important to provide parks with enough vegetation and attractive program within their living area in order to make them use green spaces. The cooperation with companies as corporate social responsibility program for developing environmental education programs might be effective.
\end{abstract}

Keywords: childhood experience, environmental education, playspace, questionnaires, satellite image

*Correspondence author, email: itaya@bio.mie-u.ac.jp, tel./fax. : +81592139513

\section{Introduction}

Urban green spaces have provided very important nearnatural environments for urban children. Activities in green spaces have positive effects on the physical and psychological health of children (Bell et al. 2008; Barton \& Pretty 2010; Almanza et al. 2012; Dadvand et al. 2018). Green spaces are a place for exploration and playing for children whether it was managed or unmanaged (Jansson et al. 2016). Green space also contributes as a place to experience nature (Coolen \& Meesters 2012) and for making friends (Seeland et al. 2009). Wu et al. (2014) and Kweon (2017) showed that children who study in school environments with more trees tended to perform better academically.

In developing countries green spaces are often destroyed and degraded for other land uses (Byomkesh et al. 2012; Ramdani et al. 2015; Agaton et al. 2016; Herwirawan et al. 2017). Due to rapid urbanization, Indonesian cities are suffering from a lack of green space. Green spaces in big cities such as Jakarta, Bandung, Surabaya, and Medan have decreased from $35 \%$ on average to less than $10 \%$ nowadays (Kirmanto et al. 2012). Along with the rapidly growing population, the area of green space per capita is also very low, for example, Jakarta has merely $7.08 \mathrm{~m}^{2} \mathrm{GS} /$ capita, compared to Stockholm $\left(80 \mathrm{~m}^{2}\right)$, New York $\left(30 \mathrm{~m}^{2}\right)$, and Paris $\left(15 \mathrm{~m}^{2}\right)$ (Kirmanto et al. 2012). In this case, Indonesian cities could not meet the standard of World Health Organization (WHO) which recommends cities to provide a minimum of $9 \mathrm{~m}^{2}$ of green area/capita (Reyes et al. 2014). With more than $53.7 \%$ of the population already lived in urban areas since 2015 (World Bank 2016) and will rise to $70 \%$ in 2050 (United Nations 2014), Indonesia must work very hard to provide green space for the citizen. Within this situation, Indonesian children, especially those in an urban area will lose the benefit provided by green space if the green space continues to decrease.

At the same time, urbanization has been thought to decrease nature related experience for children (Shanahan $e t$ al. 2017; Soga et al. 2018). The high proportion of urban areas are made of artificial material and is segregated from a natural system and process (Soga \& Gaston 2016; White et al. 2018). For the children, recent urban expansion and densification have reduced the availability of their neighborhood natural places (Turner et al. 2004; Neunoven et al. 2007; Zhang et al. 2014; Soga et al. 2016). Sedentary activities such as watching TV and playing with toys are more famous for children (Singer et al. 2009) and these activities decreased childrens' available time to engage with nature (Hoffert 2009; Singer et al. 2009). Children and youth in cities around the world are also increasingly cut off from enjoying their neighborhoods because their parents worried about safety (Gaster 1991; Johnson \& Hurley 2002). Open spaces or playground sometimes not located nearby, and children need to cross the main road (Othman \& Said 2012), and this is also one reason that increases parents' anxiety about letting their children play in green space. 
Despite all the constraints above, children in some countries were found to use and play in green space actively. Previous studies have reported childrens' use of green space in developed countries. Tandy (1999) reported 23\% of children aged between 5 and 12 years in urban Australia liked to play at parks. In another similar study in Australia, $41 \%$ of children aged between 8 and 12 years preferred to play in open areas, natural areas, parks and playgrounds (Cunninghum et al. 1996). As much as $68 \%$ of boys' and $50 \%$ of girls' activities were in outdoors in the Omaha, USA (Cherney \& London 2006). In Helsinki, children chose natural settings as favorite place although they were fewer compared to the sport and residential settings (Korpela et al. 2002), a contrast to Northern New Mexico where children still chose mountains and natural places (such as rivers, rocks, and ditches) as their favorite place (Derr 2002).

Unfortunately, studies about children's use of green space developing country such as Indonesia is very limited. Former research about green space in Malang, Indonesia mostly focused on green space availability and its function for ecosystem services such as providing oxygen (Mbele \& Setiawan 2015), reducing CO2 emission (Andriono et al. 2013), improving thermal comfort (Sunaryo 2015), and biodiversity conservation (Nisa et al. 2013). Study about green space around childrens' environment is very difficult to find. As the increase of urbanization and population continue in Indonesia (Arifin \& Nakagoshi 2011; Agaton et al. 2016), it is important to understand how children in urban area use green space. We also need to pay attention to parents, who are significantly affected childrens' use and perception of natural places, including green space (Soga et al. 2018).
Thus, in our study, we investigated the actual use of green space by parents and children in Malang, Indonesia. Our study aimed to understand the correlation between available green space around childrens' neighborhood (measured by satellite image analysis) and the actual use of green space by children and parents (measured by questionnaires).
Methods
Study site Malang is the second largest city in East Java (Figure 1), with a total area of $110.06 \mathrm{~km}^{2}$. The city is surrounded by mountains and mountain ranges, including Mt. Bromo, Mt. Butak, Mt. Arjuna, and Mt. Semeru. The southern part of Malang is a large plateau, the northern part is a fertile highland, the eastern part is a plateau with less fertile soil, and the western part is a vast plateau (Pemerintah Kota Malang 2018). The population was 820,243 based on the 2010 Census and had doubled in 40 years. It was estimated to reach 874,890 in 2020 (Badan Pusat Statistik Kota Malang 2015). Economic and population growth have been marked with steady in Malang, and the government has been unable to control the urbanization process and related population growth and urbanization (Ramdani et al. 2015). Urbanization in Malang with increasing of the housing area and decreasing agricultural and forested land is happening in the uncontrolled situation, and urban area cover increased from $21 \%$ in 2001 to $40 \%$ in 2014 (Ramdani et al. 2015). The rapid urbanization in Malang has resulted in a steady decrease in green space in the city. Our previous study reported that green space ratios around elementary schools in Malang, which was a circle of $1 \mathrm{~km}$ radius, were extremely low in the center of the city, which was under $15 \%$. It would

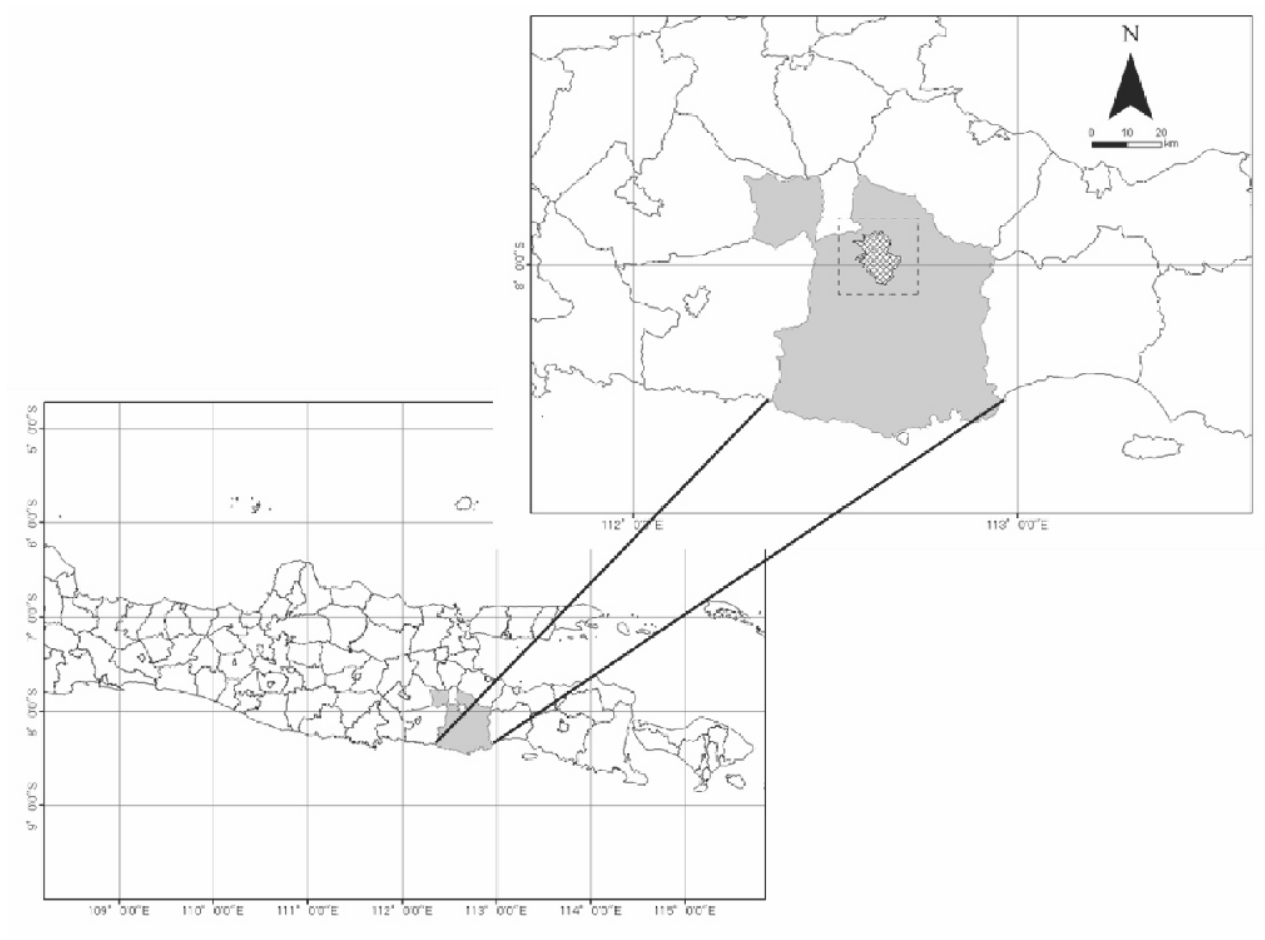

Figure 1 Location of the study site. Malang (hatched line) is located in the northern part of the Malang Regency (gray area). The area surrounded by the broken line is the area pictured in the satellite image. 
be difficult to generate more green spaces because of limited spaces. Therefore, we concluded that it is necessary to provide opportunities for children to spend in green spaces in Malang (Hartatik \& Itaya 2016).

Detection of green space near elementary schools using remote sensing As living environments of respondents, land cover distribution near elementary schools were detected using the RapidEye satellite image acquired on 20 May 2015. It was a 5-m ground spatial resolution (Figure 1). After normalized difference vegetation index (NDVI) values were calculated using red $(630,680 \mathrm{~nm})$ and near-infrared $(760,850 \mathrm{~nm})$ bands, it was combined with red, green $(520,590 \mathrm{~nm})$, and blue $(440,510 \mathrm{~nm})$ bands. The supervised classification, which was maximum likelihood classifier, was applied for the combined image. The four categories of land covers were set up: woody vegetation, non-woody vegetation, built-up, and bare land. Then, 40 training data for the classification and 200 testing data for accuracy assessment was collected represent the four land covers categories. Training data and testing data were collected by photo visual interpretation on Google Earth Pro and Google Street View. The whole image processing was carried out by ERDAS IMAGINE 2016 (ERDAS) including prior processing such as converting from the digital number values to top-of-atmosphere reflectance. Overall accuracy was $78.5 \%$, and Kappa was 0.71 for the result of classification (Story \& Congalton 1983; Congalton 1991).

As the daily living area of children, the areas of green spaces in the $2 \mathrm{~km}$ radius zones of five schools were

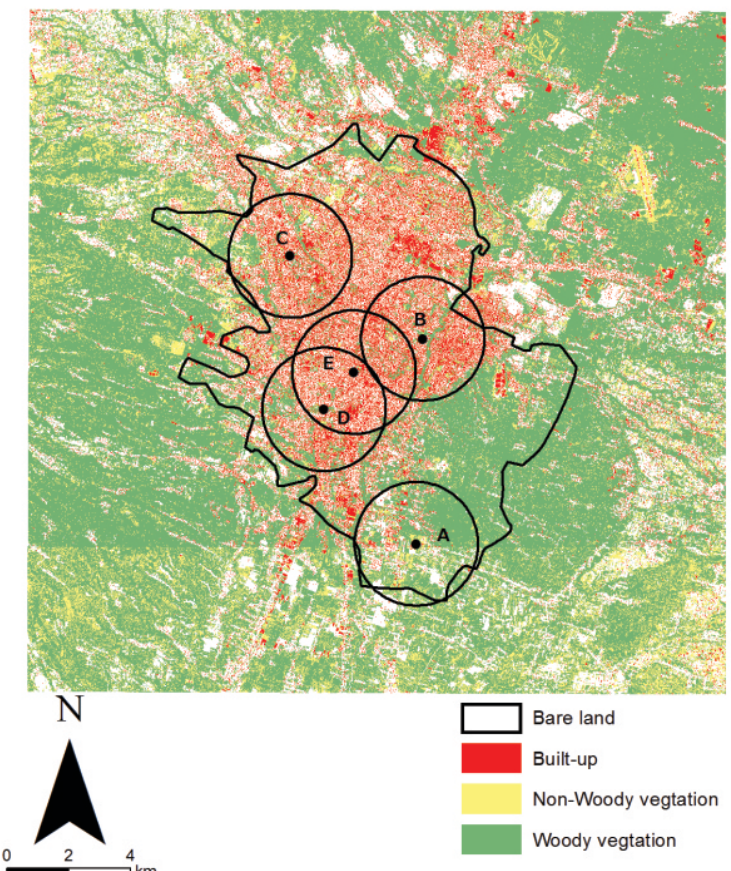

Figure 2 Land cover types in Malang detected using a satellite image. A to $\mathrm{E}$ are the school locations. The circles are the two $\mathrm{km}$ zones around the schools. The boundary line shows the boundary of the city. calculated. The reported walking rate of children is $4.3 \mathrm{~km} \mathrm{~h}^{-1}$ (McDonalds 2008), and $2 \mathrm{~km}$ can be walked in approximately 30 minutes.

Questionnaire survey for children and their parents A questionnaire survey was conducted in November 2016 to understand the actual use of green spaces by children and their parents in Malang. Malang is divided into five administrative sub-districts called kecamatan. One elementary school was chosen randomly from each kecamatan. Questionnaires were given to 30 children in grade five at each of the five elementary schools. Their parents received the questionnaires via their children.

The children were asked about their gender, whether they like to play outside, green spaces where they usually play, and green spaces where they like to visit. Their parents were asked, places where they recognized as green spaces, green spaces near their home, and green space where they visit with their children. They were also asked about their home address (sub-district and village name), their socioeconomic background including their age, education level, and income.

In this study, the actual use of green space by children and parents were understood through questionnaires, and then the strategy for increasing green space and opportunity to use green space were discussed.

\section{Results and Discussion}

General information on the respondents Figure 2 and Figure 3 show land cover types around five elementary

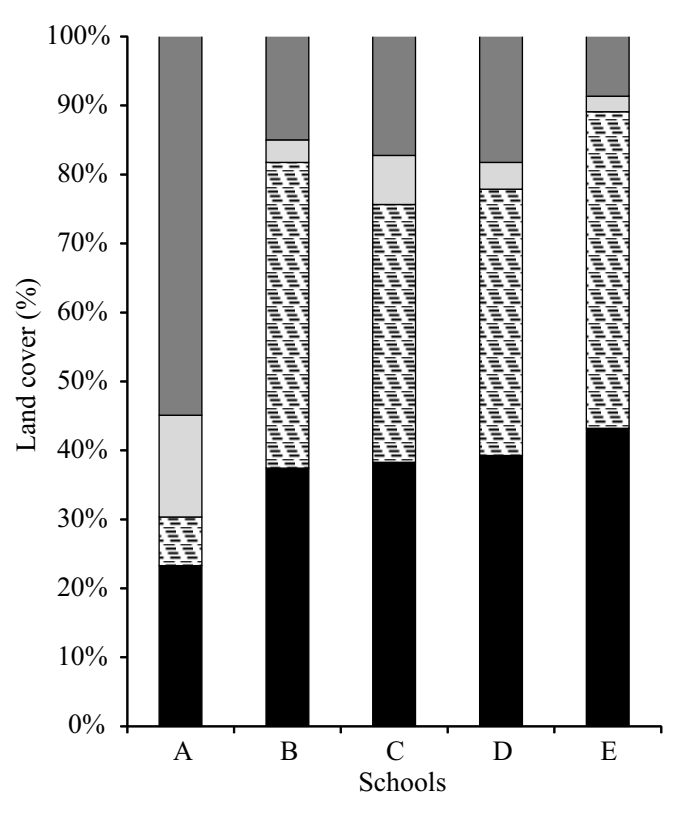

Figure 3 Land cover types in the two $\mathrm{km}$ zones around the schools. There were very few green spaces around the schools, except for school A. Woody vegetation ( $\square)$, non-woody vegetation ( $\square$ ), builtup (曰). 
schools in Malang. They share certain similarities in that composition of built-up and bare land except for school A. The area of built-up and bare land in the $2 \mathrm{~km}$ zone around school B, C, D, and E were more than $75 \%$, meanwhile the area of woody vegetation and non-woody vegetation that is considered as green spaces around school A was close to $70 \%$. Children in school A were surrounded by richer green spaces than other schools.

Table 1 shows the number of questionnaires collected and the general information of the respondents. A total of 147 $(98.0 \%)$ questionnaires were received from the children and
$145(96.7 \%)$ from their parents. More girls replied than boys, because of the gender distribution. The average age of the parents ranged from $39.2 \pm 7.67$ to $41.0 \pm 5.62$ years for the five schools. Many parents of the children in schools A and E had relatively high income and education levels compared with schools B, C, and D (Figure 4 and Figure 5).

The actual use of green spaces by children and their parents Almost all of the children liked to play outside $(86.71 \%)$. After school, they usually played in parks $(65.51 \%)$ and open fields (51.7-96.7\%). In school A, they

Table 1 Attributes of the respondents from each school

\begin{tabular}{|c|c|c|c|c|c|c|c|}
\hline \multirow{3}{*}{$\begin{array}{c}\text { Schools } \\
\mathrm{A}\end{array}$} & \multicolumn{4}{|c|}{ Children } & \multicolumn{3}{|c|}{ Parents } \\
\hline & \multirow{2}{*}{$\frac{\text { Number of answers }}{30}$} & \multirow{2}{*}{$\frac{\text { Boy }}{11}$} & \multirow{2}{*}{$\frac{\text { Girl }}{19}$} & \multirow[t]{2}{*}{ Unknown } & \multirow{2}{*}{$\frac{\text { Number of answers }}{30}$} & \multicolumn{2}{|c|}{ Average age (s.d.) } \\
\hline & & & & & & 39.4 & $(5.47)$ \\
\hline $\mathrm{B}$ & 29 & 11 & 17 & 1 & 29 & 40.7 & $(6.56)$ \\
\hline $\mathrm{C}$ & 29 & 15 & 14 & & 27 & 39.5 & $(6.43)$ \\
\hline $\mathrm{D}$ & 29 & 7 & 22 & & 29 & 39.2 & $(7.67)$ \\
\hline $\mathrm{E}$ & 30 & 15 & 15 & & 30 & 41.0 & $(5.62)$ \\
\hline Total & 147 & 59 & 87 & 1 & 145 & 40.0 & $(6.44)$ \\
\hline
\end{tabular}

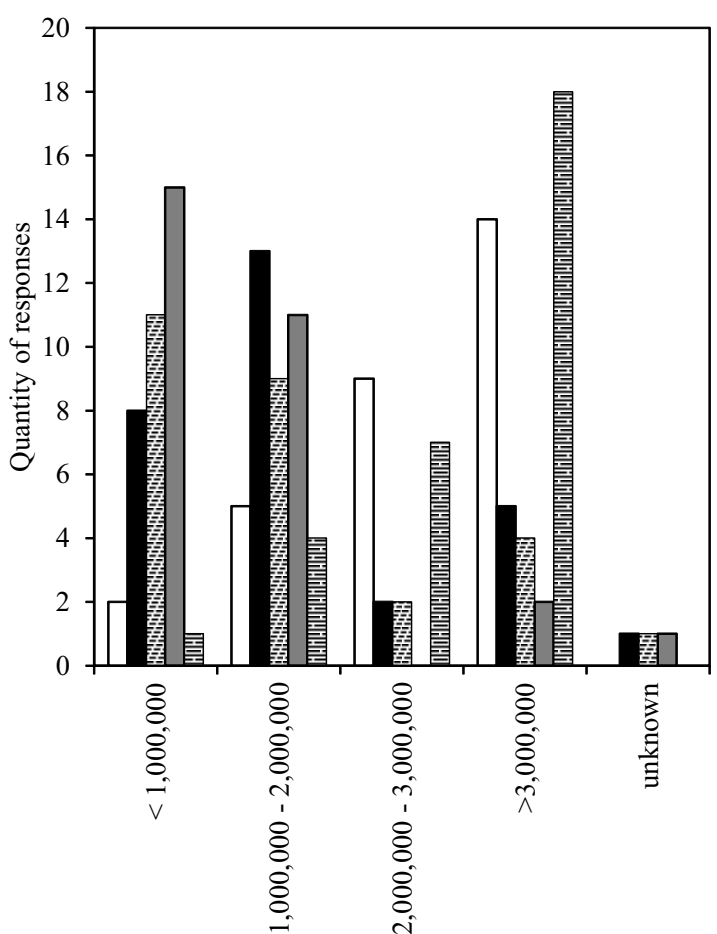

Figure 4 Distribution of the income levels of the parent respondents. Schools A and E had many parents with relatively high incomes, while schools $\mathrm{B}, \mathrm{C}$, and D had parents with moderate incomes. A ( $\square$ ), $\mathrm{B}(\square), \mathrm{C}($ 国), D(口), and E(目).

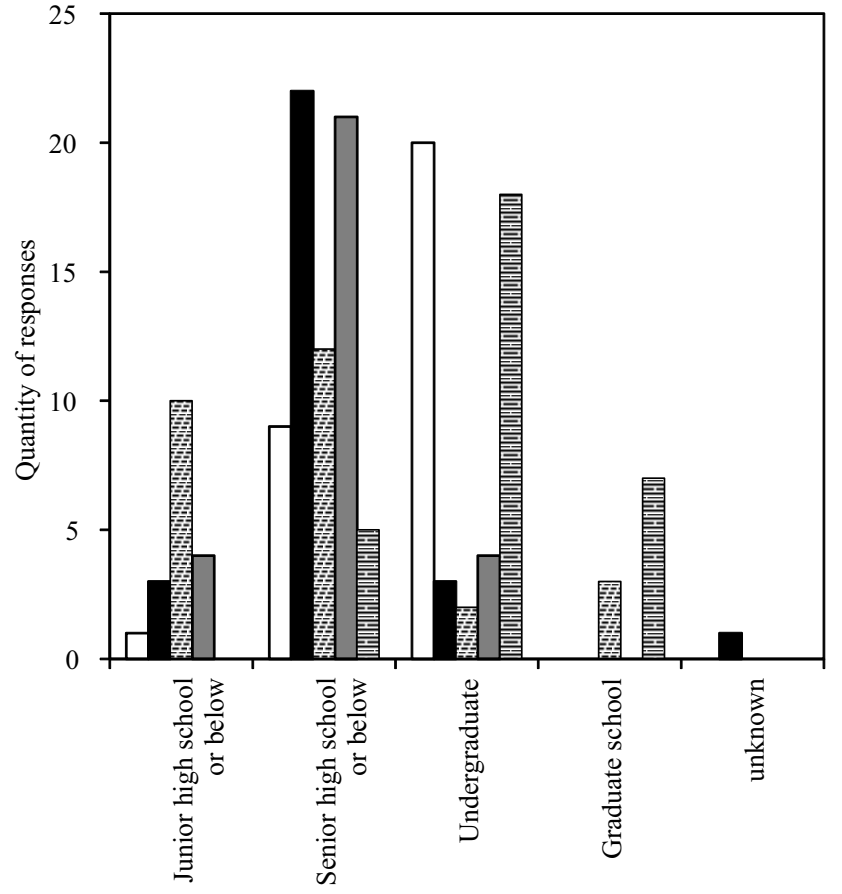

Figure 5 Distribution of the education levels of the parent respondents. Schools A and E had many parents with relatively high education, while schools B, C, and $\mathrm{D}$ had parents with moderate education. $\mathrm{A}(\square)$,

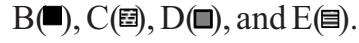



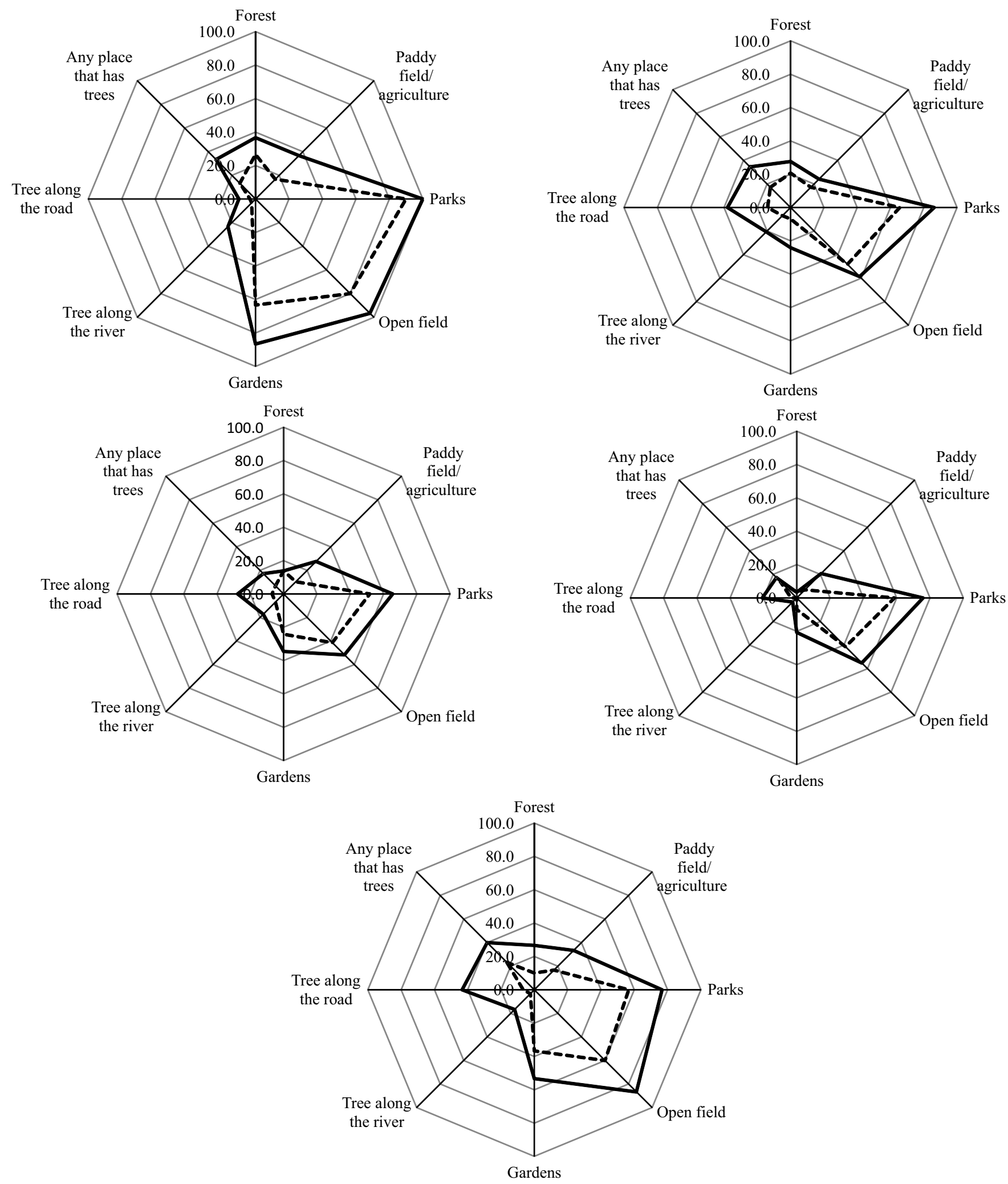

Figure 6 Answers from children for green spaces where they usually play (solid line, multiple answers) and green spaces where they like to visit (broken line, multiple answers). 
A

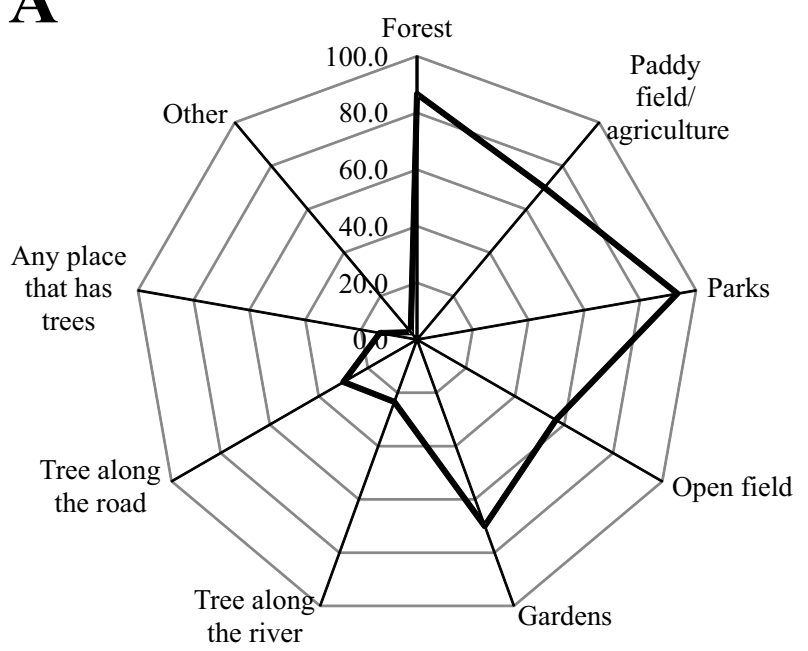

C

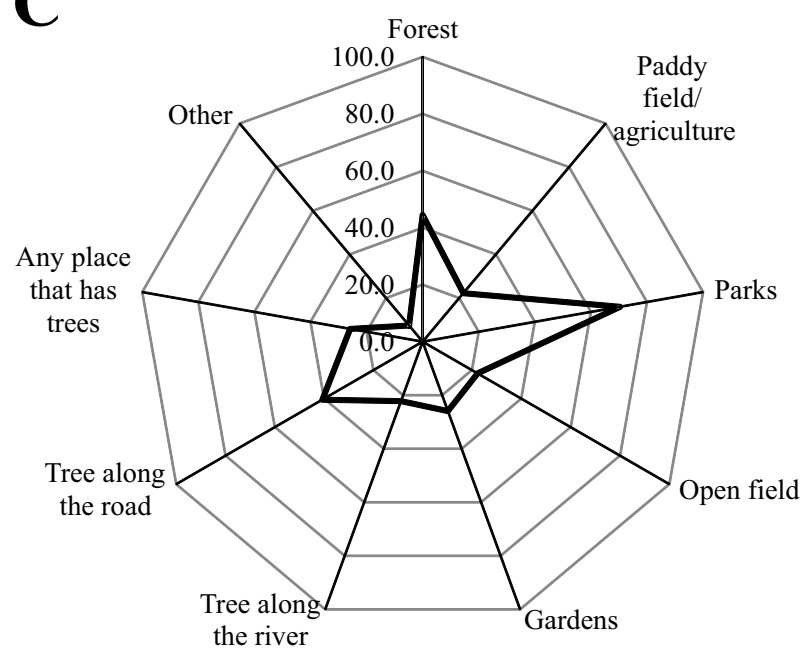

B

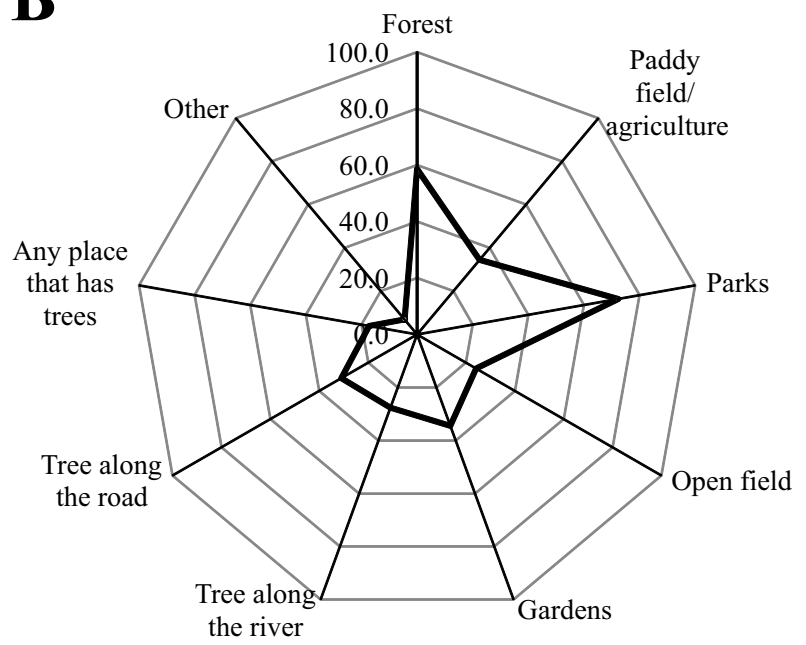

D

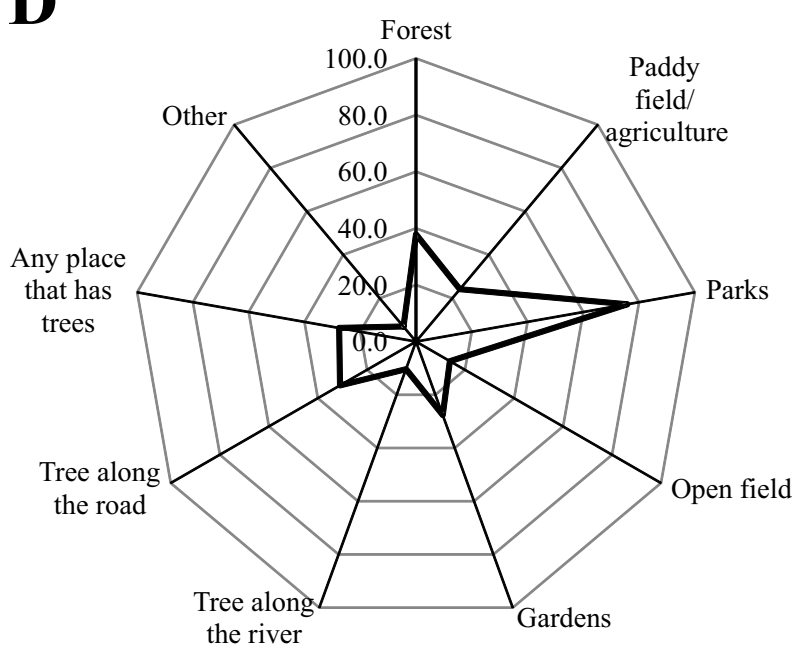

$\mathbf{E}$

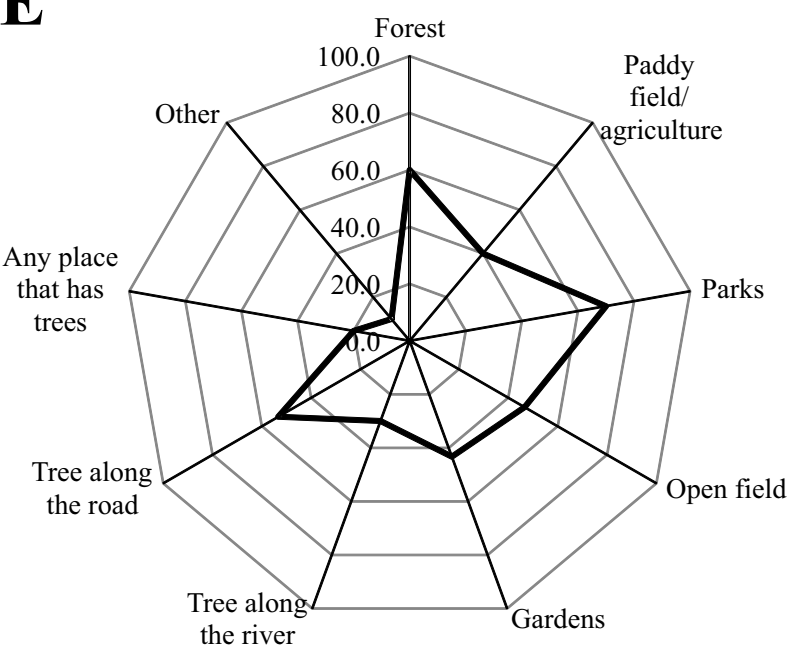

Figure 7 Answers from parents for places where they recognized as green spaces (multiple answers). 
A
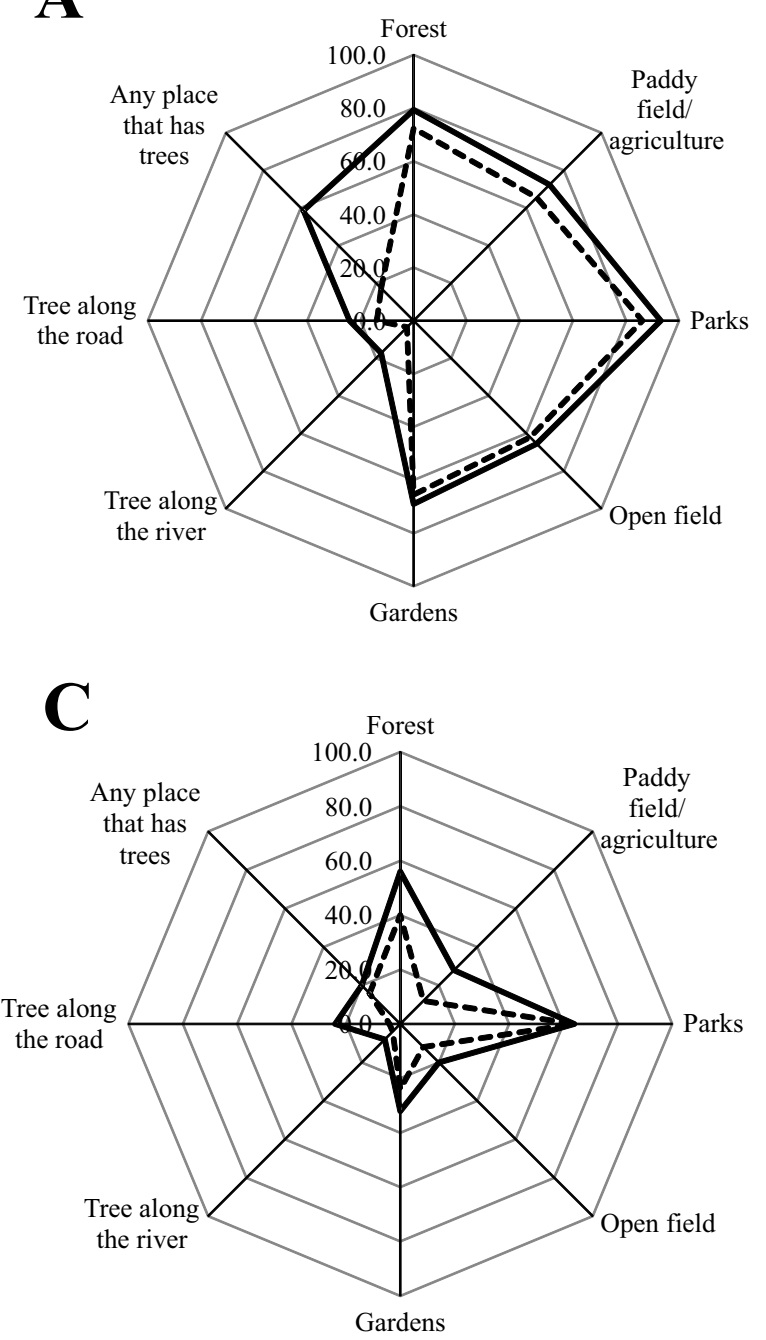
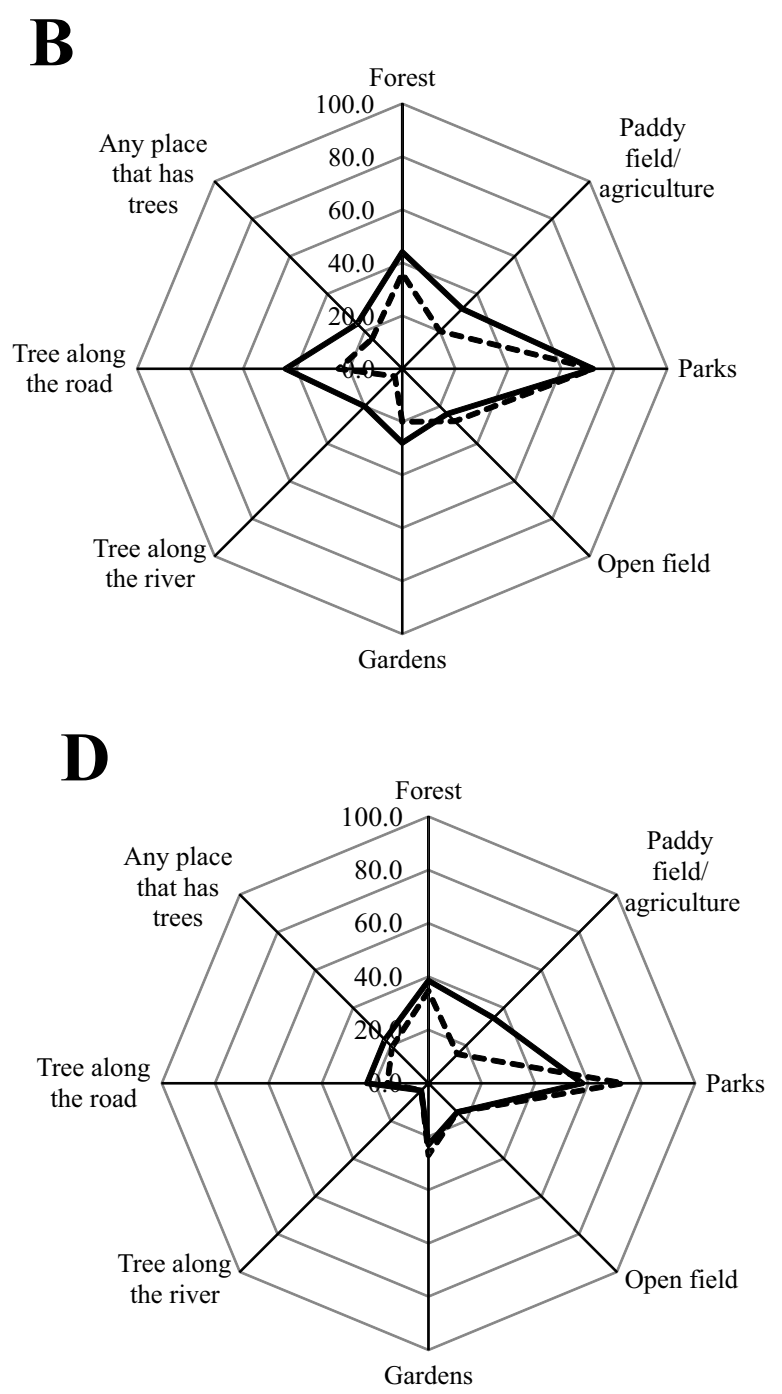

$\mathbf{E}$

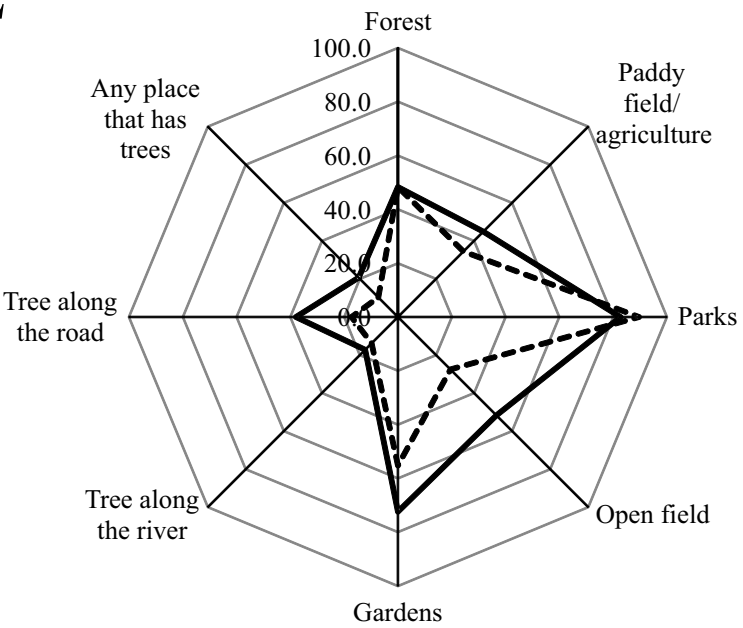

Figure 8 Answers from parents for the green spaces near their home (solid line, multiple answers) and the green space where they visit with their children (broken line, multiple answers). 
stayed in gardens $(86.7 \%)$ as well (multiple answers, solid lines in Figure 6). Children chose multiple types of green spaces for playing (2.24.2 on average). Children in school A chose significantly more places than school C and D (Steel-Dwass test, $\mathrm{p}<0.01$ ). Children in school E chose significantly more places than school D (Steel-Dwass test, $p$ $<0.05)$. There was no significant difference between schools $\mathrm{B}, \mathrm{C}$, and D and between A and E (Steel-Dwass test, $\mathrm{p}>0.05$ ). Many children preferred to play in parks (51.7-90.0\%) and open fields (41.4-80.0\%). They usually played in places where they like. In school A, they liked to play in gardens as well (multiple answers, broken lines in Figure 6). Children chose multiple types of green spaces as favorite places (1.6-3.0 in average). Children in school A chose significantly more places than school B, C, and D (Steel-Dwass test, $\mathrm{p}<$ $0.01,0.05)$. Children in school $\mathrm{E}$ chose significantly more places than school D (Steel-Dwass test, $\mathrm{p}<0.05$ ). There was no significant difference between schools B, C, and D and between A and E (Steel-Dwass test, $\mathrm{p}>0.05$ ).

Many parents recognized parks (70.0-93.9\%) and forest (37.986.7\%) as green spaces (multiple answers, Figure 7). In school A, paddy fields/agriculture $(70.0 \%)$ and garden $(70.0 \%)$ were recognized by parents as well. Parents chose multiple types of green spaces as green spaces (2.6-4.5 in average). Parents in school A chose significantly more places than school C and D (Steel-Dwass test, $\mathrm{p}<0.05$ ). There was no significant difference between schools B, C, and D and between $\mathrm{A}$ and $\mathrm{E}$ (Steel-Dwass test, $\mathrm{p}>0.05$ ). Parks (57.7-93.2\%), forests (38.5-79.3\%) and garden $(72.4 \%)$ were more identified as the green spaces near their homes (multiple answers, solid lines in Figure8). Parents in school A and E identified forests more than other schools. Parents chose multiple types of green spaces near their homes (2.2-4.8 in average). Parents in school A chose significantly more places than school B, C, and D (Steel-Dwass test, p < 0.05 ), and parents in school $\mathrm{E}$ chose significantly more places than school D (Steel-Dwass test, $\mathrm{p}<0.01$ ). There was no significant difference between schools B, C, and D and between $\mathrm{A}$ and $\mathrm{E}$ (Steel-Dwass test, $\mathrm{p}>0.05$ ). Many parents visited parks (64.0-89.7\%), forests (34.0-72.4\%) and gardens $(55.2 \%)$ with their children (multiple answers, broken lines in Figure 8). Parents who chose open fields were fewer than children. Parents in school A and E visited forests more than other schools. Paddy fields/agriculture (65.5\%) and open field $(62.1 \%)$ were more chosen by parents in school A. Parents chose multiple types of green spaces (1.8-3.9 in average). Parents in school A chose significantly more places than school B, C and D (Steel-Dwass test, $\mathrm{p}<$ $0.01,0.05)$, and parents in school E chose significantly more places than school C and D (Steel-Dwass test, $\mathrm{p}<0.05$ ). There was no significant difference between schools B, C, and $\mathrm{D}$ and between A and E (Steel-Dwass test, $\mathrm{p}>0.05$ ).

Some study reported that accessibility to green spaces is often highly stratified based on income, ethnic-racial characteristics, age, gender, ability, and other axes of difference (Byrne et al. 2009; McConnachie \& Shackleton 2010). In our study, the parents of children in schools A and $\mathrm{E}$ had higher income and education levels, while there was less green space near school E compared with school A. Schools B, C, and D, where the parents' income and education levels were moderate, and there were small green spaces around them. These backgrounds might affect the number of choice for questions with multiple answers. Children and their parents in school A and B chose more options for each question than other schools. The higher income and education levels might make extend choice variety.

While there were few green spaces around schools in Malang, especially in the center of the city, fortunately, children liked to play in the outside more than other studies (Cunninghum et al. 1996; Tandy 1999; Derr 2002; Cherney \& London 2006). However, children preferred to spend their time in well-maintained or level areas, such as parks and open fields. In Indonesia, outdoor sports such as football are very popular among children and adults. Therefore, children might prefer open spaces regardless of vegetation quantity. Parents also preferred to spend their time with their children in parks. Although their parents had also visited forests with children, it might be not frequent enough for children. Refshauge et al. (2012) reported that the variety of facilities in parks is an important factor motivating parents to bring their children. Lin et al. (2014) suggested that it is important that measures to increase people's connection to nature to encourage park visitation. Experiences with nature during childhood influence environmental views in their life (Ewert et al. 2005; Jim \& Shan 2013). Natural kindergartens and forest schools have provided such opportunities in Europe and the United States (MacEachren 2013; Elliott \& Chancellor 2014). Glackin and Jones (2012) suggested that local green spaces should be used for teaching and learning science through the study in south London. The essential qualities of children's favorite places were accessibility and a location within the route from home to other destinations (such as a friend's house or school) (Prakoso 2018). It might be important to provide parks with enough vegetation and attractive program within their living area in order to make them use green spaces. Recently, the cooperation with companies as CSR program for maintains urban parks have been progressed in Malang (Kurniawati et al. 2017). Developing environmental education programs cooperating with these companies might be possible. Since parents' income and educational levels influenced the variety of choices for green spaces, the developed program should be opened to everyone. It should be noted that urban planner should develop parks based on children preference because children have a different view from adults about their outdoor environment (Oloumi et al. 2012).

Based on the results of our study, it was clearly understood that the distribution of green space around elementary schools in Malang is not equal (Figure 2, Figure $3)$. Due to this unequal green space distribution, children also might have unequal access to green space. Strategies to tackle this issue are the management of private green space by local government through social marketing and incentive programs (Shanahan et al. 2014). Malang has private green space around 1,383 ha, which include: parks in resident and housing area, parks around office, and commercial building (institutional parks) (Peraturan Daerah Kota Malang 2011), and these private green spaces are also potential as children's play spaces.

In this study, we also revealed that parents were more actively used urban forest compared to children (Figure 6, 
Figure 7). This result may be related to children's preference for the outdoor environment. The urban forest is lacking amenities and facilities for children's play, and challenging play equipment is an important factor that attracts children to play outdoors (Aziz \& Said 2012). Parental concern about safety in the urban forest may prevent children to use it because parent's attitude about the natural environment was said to have a significant impact on children's attitude (Soga et al. 2018). In this situation, parents in Malang should show a more positive attitude towards the urban forest, for example by taking their children to visit the urban forest. They can also suggest their children go with peers because children are much more likely to play outdoors if they have friends or other children of the same age to play with (Aziz \& Said 2012).

Schools also must play an important role in encouraging children to use green space around them. Schools can cooperate with green space manager or local government to use public land near schools (such as park and urban forest) and those existing green space maybe revitalized through a school-based program (Johnson \& Hurley 2002). For study purpose, local green space can be used for teaching and learning science (Glackin \& Jones 2012). If a school has lack of school green area or has small school green area, they can redirect their green curricula project towards public green space, especially if the green space is located near the school (Ioja et al. 2014).

In general, strategy for increasing urban green space can include (Ministry of Public Work 2016):

1 enforcing the regulation about land use change, existing green space must not be changed to other land use,

2 acquisition of land for new green space by local government,

3 developing green space corridor which can act as parks connector, green space corridor can be made by planting more trees along waterways, road, and pedestrian,

4 acquisition of private green space and make it into public green space,

5 developing green wall/green roof for area with limited green space,

6 creating new regulation that supports for green city development, and

7 creating green community by encouraging local people for more actively engage in urban green space.

Previous study by Haaland and Bosch (2015) also suggested similar strategies for provision of urban green space in compact cities, including:

1 preserving green space,

2 enhancing quality of existing green space,

3 providing green space on redeveloped sites,

4 greening difficult sites lacking green space (narrow streets), and

5 smart allocation to increase visibility and visual quality.

\section{Conclusions}

The actual use of green spaces by children and their parents were found through questionnaires for them in five elementary schools in Malang, Indonesia. While children liked to play outside, their children preferred to spend their time in well-maintained or level areas, such as parks and open fields. Parents also preferred to spend their time with their children in parks. It might be important to provide parks with enough vegetation and attractive program within their living area in order to make them use green spaces. The cooperation with companies as corporate social responsibility program for developing environmental education programs might be effective.

\section{Acknowledgment}

Our deepest appreciation goes to Prof. Ishikawa who provided carefully considered feedback and valuable comments. We are also indebted to Mr. Samsudin of the Board of Education in Malang City whose meticulous comments were an enormous help to us.

\section{References}

Agaton M, Setiawan Y, Effendi H. 2016. Land use/land cover change detection in an urban watershed: A case study of upper Citarum Watershed, West Java Province, Indonesia. Procedia Environmental Sciences 33:654-660. https://doi.org/10.1016/j.proenv.2016.03. 120.

Almanza E, Jerrett M, Dunton G, Seto E, Pentz MA. 2012. A study of community design, greenness, and physical activity in children using satellite, GPS and accelerometer data. Health \& place 18:46-54. https://doi.org/10.1016/j. healthplace.2011.09.003.

Andriono F, Hanafi I, Yanuwiadi B, Soemarno. 2013. Green open space scenarios in reducing $\mathrm{CO}_{2}$ emissions in Malang City, Indonesia: A dynamic system approach. IOSR Journal of Engineering 3(6):01-13. https://doi.org/ 10.9790/3021-03640113.

Arifin HS, Nakagoshi N. 2011. Landscape ecology and urban biodiversity in tropical Indonesian cities. Landscape and Ecological Engineering 7:33-43. https://doi.org/ 10.1007/s11355-010-0145-9.

Aziz NF, Said I. 2012. The trends and influential factors of children's use of outdoor environments: A review. Procedia-Social and Behavioral Sciences 38:204-212. https://doi.org/10.1016/j.sbspro.2012.03.341.

Badan Pusat Statistik Kota Malang. 2015. Kota Malang Dalam Angka (Malang City in Figures) 2015. Badan Pusat Statistik Kota Malang. ISSN: 0215-5974. https://malangkota.bps.go.id/ [accessed on $5^{\text {th }}$ October 2018].

Barton J, Pretty J. 2010. What is the best dose of nature and green exercise for improving mental health? A multistudy analysis. Environmental Science \& Technology 44:3947-3955. https://doi.org/10.1021/es903183r.

Bell JF, Wilson JS, Liu GC. 2008. Neighborhood greenness and 2-year changes in body mass index of children and youth. American Journal of Preventive Medicine 35: 547-553. https://doi.org/10.1016/j.amepre.2008. 
07.006

Byomkesh T, Nakagoshi N, Dewan AM. 2012. Urbanization and green space dynamics in Greater Dhaka, Bangladesh. Landscape and Ecological Engineering 8:45-58. https://doi.org/10.1007/s11355-010-0147-7.

Byrne J, Wolch J, Zhang J. 2009. Planning for environmental justice in an urban national park? Journal of Environmental Planning and Management 52:365-392. https://doi.org/10.1080/09640560802703256.

Cherney ID, London K. 2006. Gender-linked differences in the toys, television shows, computer games, and outdoor activities of 5-to 13-year-old children. Sex Roles 54:717. https://doi.org/10.1007/s11199-006-9037-8.

Congalton RG. 1991. A review of assessing the accuracy of classifications of remotely sensed data. Remote Sensing of Environment 37:35-46. https://doi.org/10.1016/00344257(91)90048-B.

Coolen H, Meesters J. 2012. Private and public green spaces: meaningful but different settings. Journal of Housing and the Built Environment 27:49-67. https://doi.org/10. 1007/ s10901-011-9246-5.

Cunningham, Chris. \& Barlow, Monica. \& Jones, Margaret. \& Lismore (N.S.W.). Council. \& University of New England. Department of Geography and Planning. \& Australian Play Alliance. 1996. Town planning and children: a case study of Lismore, New South Wales, Australia. Armidale, N.S.W: Dept. of Geography and planning, University of New England.

Dadvand P, Hariri S, Abbasi B, Heshmat R, Qorbani M, Motlagh ME, Basagana X, Kelishadi R. 2018. Use of green spaces, self-satisfaction and social contacts in adolescents: a population-based CASPIAN-V study. Environmental Research 168:171-177. https://doi.org/ 10.1016/j.envres.2018.09.033.

Derr V. 2002. Children's sense of place in northern New Mexico. Journal of Environmental Psychology 22:125-137. https://doi.org/10.1006/jevp.2002.0252.

Elliott S, Chancellor B. 2014. From forest preschool to bush kinder: An inspirational approach to preschool provision in Australia. Australasian Journal of Early Childhood 39:45-53.

Ewert A, Place G, Sibthorp J. 2005. Early-Life outdoor experiences and an individual's environmental attitudes. Leisure Sciences 27:225-239. https://doi.org/10.1080/ 01490400590930853.

Gaster, Sanford. 1991. Urban children's access to their neighborhood: Changes over three generations. Environment and Behavior 23(1):70-85. https://doi.org/ $10.1177 / 0013916591231004$.

Glackin M, Jones B. 2012. Park and learn: Improving opportunities for learning in local open spaces. School
Science Review 93: 105-113.

Haaland C, Bosch CK. 2015. Challenges and strategies for urban green-space planning in cities undergoing densification: A review. Urban Forestry \& Urban Greening 14:760-771. https://doi.org/10.1016/j.ufug. 2015.07.009.

Hartatik SE, Itaya A. 2016. Estimation of accessibility to green space for children in Malang Indonesia. In: Proceeding of the 6th Annual Meeting of the Chubu Forest Society; Tsu City, October 22-23, 2016. Pp 40.

Herwirawan FX, Kusmana C, Suhendang E, Widiatmaka W. 2017. Changes in land use/land cover patterns in Indonesia's border and their relation to population and poverty. Jurnal Manajemen Hutan Tropika 23(2):90-101. https://doi.org/10.7226/jtfm.23.2.90.

Hofferth SL. 2009. Changes in American children's time 1997 to 2003. Electronic International Journal of Time Use Research 6:26-47. https://doi.org/10.13085/ eIJTUR.6.1.26-47.

Ioja CI, Gradinaru SR, Onose DA, Vanau GO, Tudor AC. 2014. The potential of school green areas to improve urban green connectivity and multifunctionality. Urban Forestry \& Urban Greening 13:704-713. https://doi.org/10.1016/j.ufug.2014.07.002.

Jansson M, Sundevall E, Wales M. 2016. The role of green spaces and their management in a child-friendly urban village. Urban Forestry \& Urban Greening 18:228-236. https://doi.org/10.1016/j.ufug.2016.06.014.

Jim CY, Shan X. 2013. Socioeconomic effect on perception of urban green spaces in Guangzhou, China. Cities 31:123-131. https://doi.org/10.1016/j.cities.012.06.017.

Johnson JM, Hurley J. 2002. A future ecology of urban parks: Reconnecting nature and community in the landscape of children. Landscape Journal 21:1-2. https://doi.org/10. 3368/lj.21.1.110.

Kirmanto D, Ernawi IS, Djakapermana RD. 2012. Indonesia Green City Development Program: An Urban Reform. In: Proceedings of Congress Report, 48th ISOCARP Congress, Perm, 2012. Pp 1-13.

Korpela K, Kyttä M, Hartig T. 2002. Restorative experience, self-regulation, and children's place preferences. Journal of Environmental Psychology 22:387-398. https://doi.org/10.1006/jevp.2002.0277.

Kurniawati DE, Kusumaningrum DN, Haffsari PP. 2017 Revitalization of green open space (GOS) in Kota Malang as the government response to urban social sustainability. Journal of Social Science and Humanities Research 2(5):1-11.

Kweon DK, Ellis CD, Lee J, Jacobs K. 2017. The link between school environments and student academic performance. Urban Forestry \& Urban Greening 23: 
35-43.https://doi.org/10.1016/j.ufug.2017.02.002.

Lin BB, Fuller RA, Bush R, Gaston KJ, Shanahan DF. 2014. Opportunity or orientation? Who uses urban parks and why? PLoS one 9 (1):e87422. https://doi.org/10.1371/ journal.pone.0087422.

MacEachren Z. 2013. The Canadian forest school movement. Learning Landscapes 7:219-233.

Mbele MFB, Setiawan RP. 2015. Penyediaan ruang terbuka hijau berdasarkan kebutuhan oksigen di kota Malang. JURNAL TEKNIK ITS 4(2):98-101.

McConnachie MM, Shackleton CM. 2010. Public green space inequality in small towns in South Africa. Habitat International 34:244-248. https://doi.org/10.1016/ j.habitatint.2009.09.009.

McDonald CN. 2008. Children's mode choice for the school trip: the role of distance and school location in walking to school. Transportation 35:23-35. https://doi.org/10. 1007/s11116-007-9135-7.

Ministry of Public Work. 2016. Strategi Peningkatan Ruang Terbuka Hijau (Strategy for Increasing Green Space). http://sim.ciptakarya.pu.go.id/p2kh/knowledge/detail/st rategi-peningkatan-ruang-terbuka-hijau [20 December 2018].

Nisa ARK, Mukti M, Hamzah MF, Mustakim A, Abidin Z. 2013. Butterflies' diversity in green open space of Malang City, East Java Province, Indonesia. The Journal of Tropical Life Science 3(2):104-107.

Neuvonen M, Sieva“nen T, To“nnes S, Koskela T. 2007. Access to green areas and the frequency of visits-A case study in Helsinki. Urban Forest Urban Green 6:235-247. https://doi.org/10.1016/j.ufug.2007.05.003.

Oloumi S, Mahdavinejad M, Namvarad A. 2012. Evaluation of outdoor environment from the viewpoint of children. Procedia-Social and Behavioral Sciences 35: 431- 439 AicE-Bs. https://doi.org/10.1016/j.sbspro.2012.02.108.

Othman S, Said I. 2012. Affordances of cul-de-sac in urban neighborhoods as play spaces for middle childhood children. Procedia-Social and Behavioral Sciences 38:184-194. https://doi.org/10.1016/j.sbspro.2012.03. 339.

Pemerintah Kota Malang. 2018. Geografis. https://malangkota.go.id/ [05 October 2018].

Regulation of Malang City Number 4 Year 2011 of Urban Land Use Plan (Rencana Tata Ruang Wilayah) Malang City Year 2010-2030. Malang: Malang City Government.

Prakoso S. 2018. Essential qualities of children's favorite places. IOP Conf. Series: Earth and Environmental Science 126:012003. https://doi.org/10.1088/1755-
1315/126/1/012003.

Ramdani F, Putra AP, Utomo BN. 2015. Historical urban land use transformation in virtual Geo-Library. ISPRS International Journal of Geo-Information 4:1500-1511. https://doi.org/10.3390/ijgi4031500.

Refshauge AD, Stigsdotter UK, Cosco NG. 2012. Adults' motivation for bringing their children to park playgrounds. Urban Forestry \& Urban Greening 11:396-405. https://doi.org/10.1016/j.ufug.2012. 06.002 .

Reyes M, Paez A, Morency C. 2014. Walking accessibility to urban parks by children: A case study of Montreal. Landscape and Urban Planning 125:38-47. https://doi.org/10.1016/j.landurbplan.2014.02.002.

Seeland K, Dübendorfer S, Hansmann R. 2009. Making friends in Zurich's urban forests and parks: The role of public green space for social inclusion of youths from different cultures. Forest Policy and Economics 11:10-17. https://doi.org/10.1016/j.forpol.2008.07.005.

Shanahan DF, Lin BB, Gaston KJ, Bush R, Fuller RA. 2016. Socio-economic inequalities in access to nature on public and private lands: A case study from Brisbane, Australia. Landscape and Urban Planning 130:14-23. https://doi.org/10.1016/j.landurbplan.2014.06.005.

Shanahan DF, Cox DTC, Fuller RA, Hancock S, Lin BB, Anderson K, Bush R, Gaston KJ. 2017. Variation in experiences of nature across gradients of tree cover in compact and sprawling cities. Landscape and Urban Planning 157:231-238. https://doi.org/10.1016/j.land urbplan.2016.07.004.

Singer DG, Singer, JL, D'Agostino H. DeLong Raeka. 2009. Children's pastimes and play in sixteen nations, is free time declining? American Journal of Play, Winter $1(3): 283-312$

Soga M, Gaston KJ. 2016. Extinction of experience: The loss of human-nature interactions. Frontiers in Ecology and the Environment 2:94-101. https://doi.org/10.1002/ fee. 1225 .

Soga M, Gaston KJ, Yamaura Y, Kurisu K, Hanaki K. 2016. Both direct and vicarious experiences of nature affect children's willingness to conserve biodiversity. International Journal of Environmental Research and Public Health 13:529 https://doi.org/10.3390/ ijerph13060529.

Soga M, Yamanoi T, Tsuchiya K, Koyanagi TF, Kanai T. 2018. What are the drivers of and barriers to children's direct experiences of nature? Landscape and Urban Planning 180:114-120. https://doi.org/10.1016/j.land urbplan.2018.08.015.

Story M, Congalton RG. 1983. Accuracy assessment: A user's perspective. Photogrammetric Engineering and 
Remote Sensing 52:397-399.

Sunaryo DK. 2015. Studi Hubungan Ruang Terbuka Hijau, Temperatur Lingkungan Perkotaan dan Kebutuhan Konsumsi Oksigen Dengan Sistem Informasi Geografis. In: Prosiding SEMINAR NASIONAL TEKNOLOGI (SENATEK) 2015 Institut Teknologi Nasional Malang, Malang, 17 January 2015.

Tandy CA. 1999. Children's diminishing play space: A study of interg-enerational change in children's use of their neighborhoods. Australian Geographical Studies 37:154-164. https://doi.org/10.1111/1467-8470.00076.

Turner WR, Nakamura T, Dinetti M. 2004. Global urbanization and the separation of humans from nature. Bioscience 54:585-590. https://doi.org/10.1641/00063568(2004)054[0585:GUATSO]2.0.CO;2.
United Nations. 2014. World Urbanization Prospects. http://esa.un.org/unpd/wup/ [20 May 2016].

World Bank. 2016 . Urban Population. http://data.worldbank.org/ [25 October 2016].

Wu DD, McNeely E, Cedeño-Laurent JG, Pan WC, Adamkiewicz G, Dominici F, Lung SC, Su HJ, Spengler JD. 2014. Linking student performance in Massachusetts elementary schools with the "Greenness" of school surroundings using remote sensing. PLOS ONE 9: e108548. https://doi.org/10.1371/journal.pone.0108548.

Zhang W, Goodale E, Chen J. 2014. How contact with nature affects children's biophilia, biophobia and conservation attitude in China. Biological Conservation 177: 109-116. https://doi.org/10.1016/j.biocon.2014.06.011. 